\title{
Betonarme Kolon Tasarımında Kullanılan İki Eksenli Moment - Eksenel Yük Etkileşim Diyargamlarının Oluşturulmasında Fiber Ve Analitik Yöntemlerin Kaşrılaştırılması
}

\author{
Erkan Akpinar $^{*}$, Eyüp Bingöl ${ }^{2}$ \\ 1* Kocaeli Üniversitesi, Mühendislik Fakültesi, İnşaat Mühendisliği Bölümü, Kocaeli, Türkiye, (ORCID: 0000-0001-6576-2362), erkan.akpinar@kocaeli.edu.tr \\ 2 MUTEK Mühendislik, İstanbul, Türkiye (ORCID: 0000-0002-0298-7887), eyupbingol59@gmail.com
}

(International Conference on Design, Research and Development (RDCONF) 2021 - 15-18 December 2021)

(DOI: 10.31590/ejosat.1043708)

ATIF/REFERENCE: Akpinar, E. \& bİNGÖL, E. (2021). Betonarme Kolon Tasarımında Kullanılan İki Eksenli Moment - Eksenel Yük Etkileşim Diyargamlarının Oluşturulmasında Fiber Ve Analitik Yöntemlerin Kaşrılaştırılması. Avrupa Bilim ve Teknoloji Dergisi, (32), 917-927.

\section{$\ddot{O} z$}

Betonarme yapılarda kolonlar, gerek yapı ağırlığı gibi düşey yükler etkisinde, gerekse deprem gibi yatay etkiler altında, yapının ayakta kalmasını sağlayan düşey taşıyıcı elemanlardır. Kolonlar, yapılarda düşey yönlü eksenel yüklerle birlikte yatay kuvvetleri de karşılamak üzere tasarlanmaktadırlar. Taşıyıcı elemanların moment kapasiteleri, üzerindeki eksenel yük seviyesi ile birlikte değişkenlik göstermektedir. Bu nedenle modern yapı şartnamelerinin tünümde olduğu üzere, eksenel yükün göz ardı edilemeyecek seviyede olduğu taşıyıcı elemanların tasarımında bu değişkenlik, moment - eksenel yük etkileşim ilkeleri ile tasarıma dahil edilmek zorundadır. Moment - eksenel yük etkileşim diyagramları, kolonların tasarımında bu değişkenliği hesaba katmak için kullanılmaktadır. Kolonlar için etkileşim diyagramlarının analitik olarak oluşturulması, tek eksenli moment durumu için oldukça basit denebilecek bir işlemdir. Ancak gerçekte olduğu gibi iki eksenli moment etkisi altında bu etkileşimin ortaya konulması, karmaşık hale gelmektedir. Kesitin derinlik boyunca dilimlere/parçalara ayrılarak, birim deformasyon profiline bağlı gerilme ve bunun yanında alanlara bağlı bileşke kuvvet hesaplarının, bu dilimler/parçalar üzerinde yapılmasına ve parçalarda elde edilen etkilerin birlikte hesaba katılarak sonuçların elde edilmesine, fiber yöntemle kesit analizi ismi verilmektedir. Elemanların moment kapasiteleri ve etkileşim diyagramları, analitik yöntemin yanında fiber analiz yöntemiyle de elde edilebilmektedir. Pratikte sıklıkla kullanılan analiz programları, kesit analizleri ve kolon tasarımları için bu yöntemleri kullanmaktadırlar. Bu çalışmada iki eksenli moment - eksenel yük etkileşim diyagramının elde edilmesi adına, analitik yöntem için bir algoritma kurgulanmıştır. Literatürde ve kaynaklarda tek eksenli eğilme altında oldukça basit olarak açıklanan bolca örneğe yer verilen etkileşim diyagramları, iki eksenli durumda tasarım mühendisleri için oldukça karmaşık hale gelmektedir. Genelde iki eksenli duruma yönelik açıklamalı örneğe pek rastlanmayan etkileşim diyagramları için açılayıcı örnekler ve bilgisayar programı algoritması oluşturulmuştur. Kesit analizinde, XTRACT programında fiber analiz yöntemi kullanılırken, oluşturulan algoritmada ve Section Designer modülünde analitik yöntemden faydalanılmıştır. Analitik yöntemi temel alan bilgisayar programıyla kesit analizi yapılarak elde edilen iki eksenli etkileşim diyagramları, aynı analitik yöntemi kullanarak elde edilen SAP2000 Section Designer modülü sonuçları ile kıyaslanmıştır. Her iki analitik yöntem sonuçları ise fiber analiz yöntemini baz alan XTRACT programı yardımıyla elde edilen sonuçlarla karş̧laştırılmıştır. Elde edilen etkileşim diyagramı grafiklerinin karşılaştırılmasından, analitik yöntemle ulaşılan sonuçların güvenli tarafta kaldığı görülmüştür. Tek eksenli durum için analitik yöntemin ve fiber yöntemin, benzer sonuçlar verdiği belirlenmiştir. Ancak fiber analiz yönteminde, özellikle beton üzerindeki gerçek gerilme dağılımının ve malzeme davranış modelinin göz önüne alınabilmesi sebebiyle, iki eksenli moment etkisi durumunda daha gerçekçi sonuçların elde edilebildiği görülmüştür.

Anahtar Kelimeler: Betonarme, Kolon, Moment - Eksenel Yük Etkileşim Diyagramı, Kesit Analizi, Fiber Yöntemle Kesit Analizi

\footnotetext{
*Sorumlu Yazar: erkan.akpinar@kocaeli.edu.tr
} 


\title{
Comparison of Fiber and Analytical Methods for Construction of Biaxial Moment - Axial Load Interaction Diagrams for Reinforced Concrete Column Design
}

\begin{abstract}
Columns in reinforced concrete structures are vertical load-bearing elements that allow the structure to stand under the influence of vertical loads such as the weight of the structure and lateral effects such as earthquakes. Columns are designed to withstand lateral forces as well as vertical axial loads in structures. The moment capacities of load-bearing elements vary with respect to the axial load level on them. For this reason, as in all modern building codes, this variability must be included, with the principles of moment - axial load interaction, in the design of load-carrying elements where the axial load cannot be ignored. Moment - axial load interaction diagrams are used to account for this variability in the design of columns. Analytical generation of interaction diagrams for columns is a fairly simple process as far as uniaxial moment is concerned. However, introducing this interaction under the effect of biaxial moment, as in reality, becomes complicated. The process of dividing a cross-section into slices/pieces along the depth, calculating the stress due to the unit deformation profile, as well as the resultant force with respect to the areas of these slices/pieces, and obtaining the resultant effect of the calculations acquired from these pieces, is called the cross-sectional analysis with fiber method. The moment capacities and interaction diagrams of structural members can be obtained by the analytical method as well as fiber analysis method. Analysis programs, which are frequently used in practice, use these methods for cross-sectional analysis and column designs. In this study, an algorithm for the analytical method is constructed in order to obtain the biaxial moment - axial load interaction diagram. Interaction diagrams, which are explained quite simply under uniaxial bending in the literature and other resources, with plenty of examples, become quite complex for design engineers in the biaxial case. Explanatory examples and a computer algorithm have been created for interaction diagrams, which are not often encountered for the biaxial situation. In the cross-sectional analysis, the fiber analysis method was used in the XTRACT program, while the analytical method was used in the created algorithm and the SAP2000 Section Designer module. Biaxial interaction diagrams obtained by performing cross-sectional analysis with a computer program based on the analytical method were compared with the results of the SAP2000 Section Designer module based on the same analytical method. The results of both analytical methods were compared with the results obtained with the help of the XTRACT program based on the fiber analysis method. From the comparison of the interaction diagram graphs, it was observed that the results obtained by the analytical method were on the safe side. It has been determined that the analytical method and the fiber method give similar results for the uniaxial case. However, in the fiber analysis method, it has been observed that more realistic results can be obtained in the case of biaxial moment effect, especially since the actual stress distribution on the concrete and the material behavior model can be taken into account.
\end{abstract}

Keywords: Reinforced Concrete, Column, Moment - Axial Load Interaction Diagram, Cross-Sectional Analysis, Cross-Sectional Analysis with Fiber Method

\section{Giriş}

Kolonlar, özellikle betonarme perde duvar veya çapraz eleman bulunmayan yapılarda, düşey yüklerin güvenle zemine aktarılmasını ve yatay yüklerin taşınmasını sağlayan elemanlardır. Kolonların tasarımında ve/veya imalatında oluşabilecek herhangi bir problem, yapı güvenliğini tek başına tehlikeye atabilir. Betonarme kolonların tasarımı, hem düşey hem de yatay yük taşıma zorunluluğundan dolayı, söz konusu iki etkinin birlikte değerlendirildiği moment (M) - eksenel yük (N) etkileşimi gözetilerek yapılmak zorundadır. Zira eksenel yükün, betonarme kesitlerin moment kapasitesi üzerinde önemli etkisi bulunmaktadır. Deprem doğrultusu, bina yerleşimi ve binadaki kütlelerin dağılımı, kolonlar üzerinde değişken açılarda eğilme momenti oluşmasına sebep olmaktadır. Deprem etkisinin yanında, binadaki düşey yüklerin mekansal farklılıkları kolonlar üzerinde, sabit veya göreli uzun sürede değişkenliğe sahip, iki eksenli eğilme momentlerinin oluşmasına yol açmaktadır. Açıç̧a anlaşıldığı üzere, kolonlar moment etkisi anlamında, genellikle çok eksenli eğilme etkisi altında olan elemanlardır.

Prizmatik şekle sahip betonarme kolonların tasarımı, genelde hâkim olan düşük seviyedeki mühendislik pratiğinde, ana eksenleri baz alınarak, iki ana eksen için ayrı ayrı olmak üzere, tek eksenli eğilme ve eksenel kuvvet etkileşimi göz önüne alınarak yapılmaktadır (Tek eksenli bileşik eğilme, $N-M_{x}$ ve N$\mathrm{M}_{\mathrm{y}}$ ). Kolon kesitinin iki ana ekseninde elde edilen etkileşim diyagramlarının ortak etkisi, literatürde yer alan ve şartnamelere de girmiş bulunan amprik formüllerle hesaba katılmaktadır. Bresler Yöntemi, İngiliz Betonarme Yönetmeliği Yöntemi ve Çakıroğlu-Özer Yöntemi, kolonların tasarımında tek eksenli bileşik eğilme sonuçlarından yararlanarak, eğik eksenli bileşik eğilme etkisini yaklaşık olarak hesaplamak için kullanılan yöntemler olarak sayılabilir (Ersoy ve Özcebe 2012). Doğrudan eğik eksenli bileşik eğilme yerine, tek eksenli bileşik eğilme hesabının tercih edilmesinin sebebinin, teknik hesaplama kabiliyetinin ve bilgisayar olanaklarının sınırlı olduğu eski zamanlardan kalma, basitleştirilmiş çözümleme yaklaşımı ve alışkanlığı olduğu düşünülmektedir ki halen daha bu yaklaşımın süregeldiği bilinmektedir. Günümüz hesaplama kabiliyetinin ve hızının artmasına bağlı olarak, ortalama ve yüksek seviyedeki mühendislik pratiğinde ise kolonlara etkiyen iki ana eksendeki eğilme momentleri ve eksenel kuvvetin etkileşimi aynı anda göz önüne alınarak, olması gerektiği gibi bir bütün olarak kolon tasarımına konu edilmektedir (Eğik eksenli bileşik eğilme, $\mathrm{N}-\mathrm{M}_{\mathrm{x}}-$ $\mathrm{M}_{\mathrm{y}}$ ). Gerçekte kolonlar üzerindeki açılı kuvvet etkisinin doğrudan değerlendirildiği eğik eksenli bileşik eğilme sonuçlarıyla, iki ana 
eksendeki tek eksenli bileşik eğilme sonuçlarının birlikte değerlendirildiği yaklaşımdaki sonuçlarının birbirinden farklı olduğu bilinmektedir (Ersoy ve Özcebe 2012, Doğangün 2013, Topçu 2013, Moehle 2015).

Betonarme yapılarda eleman eğilme tasarımı, kesit üzerinde bulunan eksenel yükün değerine göre şekillenmektedir. Diğer betonarme tasarım şartnamelerinde olduğu gibi Türk Betonarme Tasarım Şartnamesi olan Betonarme Yapıların Tasarım ve Yapım Kuralları Şartnamesinde (TS500-2000) de eğilme tasarımı, eleman üzerinde eksenel yük oranının \%10'un üzerinde olması durumunda salt eğilmeye göre değil, bileşik eğilme hesabı olarak adlandırılan moment - eksenel yük etkileşimine göre yapılmaktadır. Elementer analitik çözüm yönteminde, serbest cisim diyagramı üzerinde eksenel yükü de dahil ederek statik denge yazılmakta ve çözüm elde edilmektedir (Ersoy ve Özcebe 2012, Doğangün 2013, Topçu 2013, Moehle 2015). Bu denge hesabında temel yaklaşım, ilgili basınç ve çekme alanlarındaki bileşke kuvvetlerin değerlerinin ve uygulama noktalarının bulunmasıdır. Kesit üzerindeki öngörülen dış eksenel kuvvet, belirtilen bileşke kuvvetlerin değerinde ve basınç bölgesindeki bileşkenin uygulama yerinde değişime sebep olmaktadır. Bu da farklı eksenel yük değerleri için kestin moment kapasitesini değiştirmektedir. Beton basınç bölgesindeki, basın bileşke kuvvetinin değerinin ve yerinin bulunması için farklı yaklaşımlar kullanılabilmektedir. Kesitteki beton basınç bölgesi üzerinde sargılı veya sargısız gerçek beton gerilme dağılımının göz önüne alınması, en genel ve gerçekçi yaklaşımdır. Bu yaklaşımda gerçek beton gerilme dağılımının fonksiyon olarak hesaba katılmasındaki zorluktan dolayı, eşlenikdikdörtgen beton basınç bloğunun kullanım yaklaşımı, daha yaygın olarak tercih edilmektedir. Gerçek basınç dağılımının daha kolay biçimde uygulanmasını sağlayan, kesiti dilimlere/parçalara ayırarak herbir parçanın birim deformasyon değerine göre parça üzerinde oluşan basınç gerilmesinin hesaba katılmasını sağlayan yaklaşıma, fiber kesit analizi yöntemi adı verilmektedir (Wang and Hsu 1992, Moehle 2015). Belirtilen herbir yaklaşımda, hesaplama adımlarından dolayı farklı sonuçlar ortaya çıkabilmektedir. İki eksenli eğilme durumunda, basınç alanlarında da değişimler söz konusudur. Bu çalışmada söz konusu yaklaşımlar sonucu moment - eksenel yük etkileşiminde ortaya çıkan farklılıklar, karşılaştırılmalı olarak ele alınmıştır.

Moment - eksenel kuvvet etkileşimi, sadece yeni binaların yapınımda kolon tasarımı için değil, aynı zamanda mevcut binaların deprem performansının incelenmesinde, kolon performans değerlendirilmesi için de kullanılmaktaktadır. Performans değerlendirilmesi için pratikte kullanılan programlar, moment - eksenel yük etkileşimini, alternatifli veya alternatifsiz olarak, yukarıda değinilen yaklaşımları kullanarak değerlendirmeye almaktadırlar. Bu nedenle, moment - eksenel yük etkileşim diyagramlarınının oluşturulmasındaki, bir başka değişle kolon eğilme hesaplarının gerçekleştirilmesinde, özellikle eğik eksenli bileşik eğilme durumunda, kesit hesabındaki yaklaşımların getirdiği bu farklılıkların tasarım veya değerlendirme yapan mühendis tarafından bilinmesi ve göz önüne alınması önem arz etmektedir.

\section{Eŭilme Etkisindeki Kolonların Kesit Hesapları}

\subsection{Taşıma Gücü İlkesine Göre Genel Prensipler}

Yapı ve yapı elemanı tasarımında, güvenlik anlamında farklı ilkeler ve yaklaşımlar kullanılagelmiştir. $\mathrm{Bu}$ yöntemler emniyet gerilmesi yöntemi, yük katsayıları yöntemi ve sınır durumlar yöntemi olarak sayılabilir. $\mathrm{Bu}$ yöntemler arasında, yeterli güvenliği oluşturacak biçimde elastik ötesi davranışı da göz önüne almaya olanak veren, malzeme ve eleman dayanımından en etkili şekilde yararlanmayı sağlayan yöntem sınır durumlar yöntemidir. Betonarme yapı tasarımında, dünya genelindeki modern şartnamelerin tümünde, sınır durumlar yönteminin dayanım sınır durumu biçimi olan taşıma gücü ilkesi kullanılmaktadır. Taşıma gücü ilkesine göre özetle, arttırılmış ve kombine edilmiş yükler altında elemanlarda/kesitlerde oluşan iç kuvvetlerin, hiçbir durumda azaltılmış eleman/kesit dayanımlarının üstünde olmasına izin verilmez ve böylelikle yapı güvenliği sağlanmış olur.

Taşıma gücü ilkesine göre kesit hesaplarında, farklı ülke şartnamelerine göre nüsanlar bulunmaktadır. $\mathrm{Bu}$ çalışmada, Türkiye'de kullanımda olan güncel betonarme yapı tasarım şartnamesi TS500-2000'deverilen taşıma gücü ilkeleri baz alınmıştır. Aşağıda taşıma gücü ilkesine göre yapılacak kesit hesaplarında kullanılan temel varsayımlar ve kabuller yer almaktadir (TS500-2000).

a. Betonun çekme dayanımı, yok kabul edilerek ihmal edilir.

b. Donatı ile beton arasındaki aderansın,gerilme aktarımını olumsuz etkilemeyecek biçimde tam olduğu kabul edilir. Kesitte, aynı düzeydeki beton ve donatı(lar) aynı birim şekil değiştirme düzeyindedirler.

c. Eğilmeden önce düzem olan kesitler, eğilmeden sonra da düzlem kalır.

d. Taşıma gücüne ulaşıldığında, en dış beton lifindeki birim kısalma, $\varepsilon_{\mathrm{CU}}=0,003$ olarak kabul edilir. Şekil 2.1'de kesit görüntüsü ve birim deformasyon dağılımı verilmiş olup, bu durum şekil üzerinde gösterilmiştir.

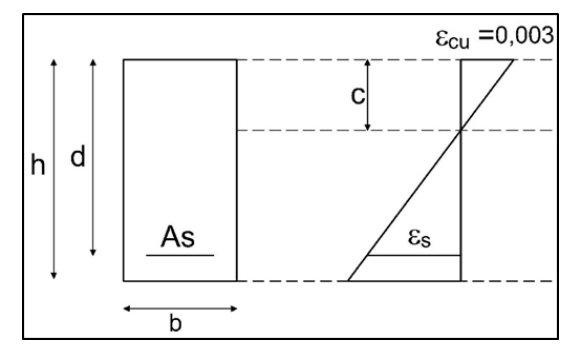

Şekil 2.1: Kesit görünümü ve birim şekil değiştirme dağılımı

e. Donatı çeliğinde pekleşme ihmal edilerek, elasto plastik davranış olduğu varsayımı yapılır. Şekil 2.2'de çelik için ideal gerilme-birim deformasyon eğrisi görülmektedir. Donatı çelikleri için $\mathrm{E}_{\mathrm{s}}=200.000 \mathrm{MPa}$ ve kopma birim uzaması $\varepsilon_{\mathrm{SU}}=0,10 \mathrm{kabul}$ edilir.

$$
\sigma_{s}=E_{s} \varepsilon_{s} \leq f_{y}
$$




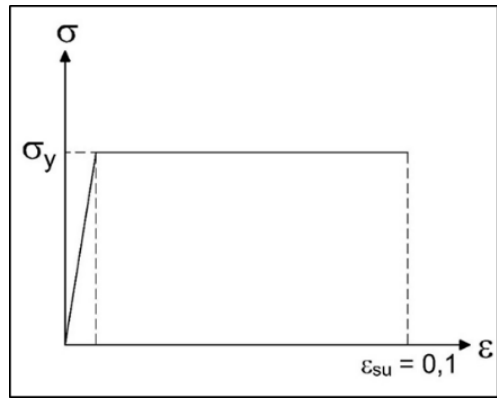

Şekil 2.2: Varsayılan donatı çeliği elasto-plastik davranışı

e. Hesaplarda kolaylık sağlaması amacıyla, gerçek beton basınç gerilmesi dağılımı yerine, eşdeğer dikdörtgen basınç bloğu kullanılabilir. Eşdeğer basınç gerilmesi 0,85.f $f_{\text {cd }}$ ve eşdeğer blok yüksekliği $\mathrm{a}=\mathrm{k}_{1}$.c olduğu varsayım yapılır. Kullanılacak olan $\mathrm{k}_{1}$ değerleri TS500-2000 Çizelge 7.1'den alınmaktadır. Burada göz ardı edilmemesi gereken nokta, TS500-2000'e göre söz konusu hesaplardaki eşdeğer dikdörtgen basınç bloğu için kullanılan $\mathrm{k}_{1}$ değeri, C50 sınıfı beton seviyesine kadar tanımlanmış olduğudur. Daha yüksek sınıftaki betonlara ait basitleştirilmiş eşlenik davranışlar için ilgili sınıfa uygun basitleştirmeler ve katsayılar kullanılmalıdır.

Bu varsayımların yanında, TS500-2000'e göre yapılmakta olan standart kesit analizinde, betonun zamana bağlı davranışının ve kesme davranışının ihmal edildiği unutulmamalıdır.

Yukarıda verilen varsayımlar ışı̆̆ında, betonarme kesitlerde taşıma gücü ilkelerine göre yapılacak eğilme hesaplarında temel alınan birim deformasyon ve gerilme dağılımları ve bileşke kuvvetlerin gösterimi Şekil 2.3'te yer almaktadır.

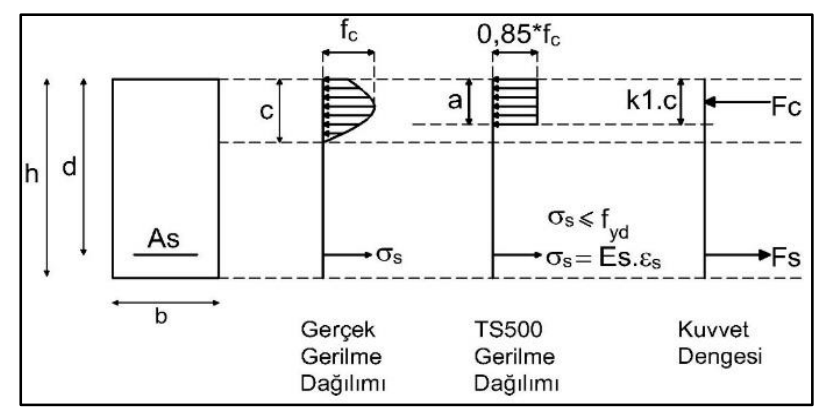

Şekil 2.3: Kesit analizinde kullanılan TS500 ile uyumlu birim deformasyon ve gerilme dağllımlarının gösterimi

\subsubsection{Basit Ĕ̈ilme Etkisinde Moment Kapasitesinin Hesaplanmast}

Eksenel basınç yükününün $(\mathrm{N}), \mathrm{f}_{\mathrm{c}} \cdot \mathrm{A}_{\mathrm{c}}$ eksenel basınç kapasitesine $\left(\mathrm{N}_{0}\right)$ oranı belirli bir değerden küçük olan elemanlar, eğilme hesalarında eksenel yükün etkisi ihmal edilerek, basit eğilme elemanı olarak tanımlanır. TS500-2000 ve T.B.D.Y.2018 'de bu oran $\left(\mathrm{N} / \mathrm{N}_{0}\right)$ 0,1 olarak tanımlanmıştır.

Taşıma gücü yöntemine göre, kesitte basınç bölgesinde, en diştaki beton lifi $\varepsilon_{\mathrm{CU}}=0,003$ 'e ulaştığı andaki kurulan denklemleri ile moment kapasitesi hesaplanmaktadır. Moment kapasitesi hesabında ilk adım olarak tarafsız eksen c'nin bulunması ile ilgili uygunluk denklemlerinden yararlanılır (Ref Ersoy kitap ). Ancak bu çalışma kapsamında, bilgisayar ortamında yapılacan kesit analizlerinde, iteratif deneme yanılma yöntemi kullanılmış olup, denge denklemi kurulduktan sonra öncelikle c varsıyımı yapılmış ve iterasyon ile denge denklemini sağlayan doğru c değeri elde edilmiştir. Kesitin denge denkleminin türetildiği dağılımlar ve bileşke kuvvetler, Şekil 2.4'de görülmektedir. Bu iteratif yöntem ile kesit göçme türünden ve şekilden bağımsız olarak c elde edilebilmektedir.

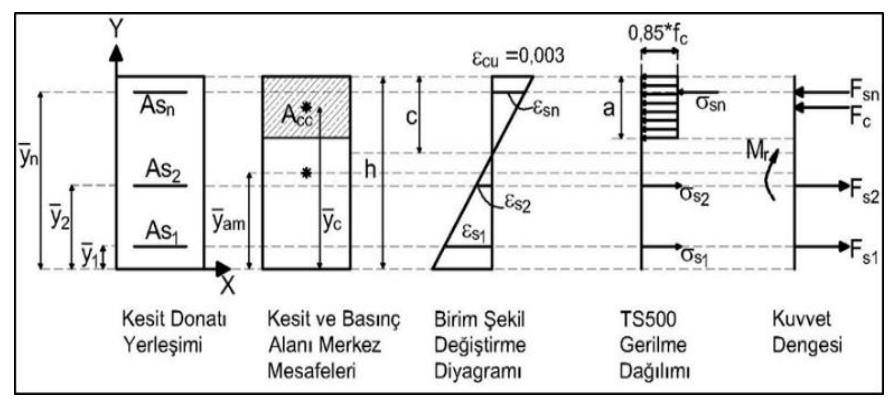

Şekil 2.4: Basit eğilme için kesit analizinde genel kuvvet dengesinin gösterimi

Basit eğilme etkisi altında, kesit analizinde kullanılan söz konusu iteratif yöntemin genel adımları, şu şekilde sıralanabilir.

Mantıklı olabilecek bir c varsayımı yapılır.

Taşıma gücü durumu için birim şekil değiştirme dağılımı kesit üzerinde çizilir. Üçgen benzerlikleri kullanılarak, her bir donatı alanı $A_{S}$ için $\varepsilon_{\mathrm{S}}$ değerleri işareti ile hesaplanır (Denklem 2.2).

$$
\varepsilon_{s}(i)=(c-h+\bar{y}(i))\left(\frac{\varepsilon_{c u}}{c}\right)
$$

Donatı çeliğinin elasto-plastik davranışına bağlı kalarak ve Denklem 2.1'de verilen gerilme ilişkisi kullanılarak, her bir donat1 alanı, $A_{S}$ için gerilme değerleri, $\sigma_{\mathrm{S}}$ yönü ile hesaplanır (Denklem 2.3).

$$
\begin{aligned}
& \sigma_{s}(i)=\varepsilon_{s}(i) E_{s} \quad\left(\left|\varepsilon_{s}\right|<f_{y} / E_{s}\right) \\
& \sigma_{s}(i)=f_{y} \quad\left(\left|\varepsilon_{s}\right| \geq f_{y} / E_{s}\right)
\end{aligned}
$$

Denge denkleminde, donatı alanlarındaki bileşke kuvvet değerleri, her bir alanın karşılığındaki gerilme değerleriyle çarpılarak, yönü ile birlikte bulunmaktadır (Denklem 2.4). Beton bileşke kuvvetinin yönü, pozitif yön olarak kabul edilmiştir.

$$
F_{s}(i)=\sigma_{s}(i) A_{s}(i)
$$

Eşdeğer basınç bloğunun etkidiği alan $\mathrm{A}_{\mathrm{CC}}$, dikdörtgen kesitlerde Denklem 2.5 ile bulunmaktadır.

$$
A_{c c}=a . b \quad a=k_{1} c, \quad a<h
$$

Eşdeğer basınç bloğunun etkidiği alan ile eşdeğer basınç gerilmesinin çarpılmasıyla, betonda oluşan basınç bileşke kuvveti elde edilir (Denklem 2.6).

$$
F_{c}=0,85 f_{c} A_{c c}
$$

Kesite etkiyen eksenel yük olmadığ 1 için denge denklemi, beton ve donatı bileşke kuvvetleri kullanılarak kurulur (Denklem 2.7). Donatı bileşke kuvvetleri, Denklem $2.2^{\prime}$ den itibaren yönleri ile türetildiğinden dolayı, herhangi bir işaret karmaşası bulunmamaktadir.

$$
F_{c}+\sum_{i=1}^{n} F_{s}(i)=0
$$


Birinci adımda varsayılan tarafsız eksen c değeri, Denklem 2.7'deki eşitlik sağlanana kadar değiştirilerek doğru c değerine ulaşılır.

Moment kapasitesi $\mathrm{M}_{\mathrm{r}}$, tüm kuvvetlerin kesitin ağırlık merkezine göre moment alınması ile hesaplanır (Denklem 2.8). $\mathrm{M}_{\mathrm{r}}$ hesabında saat yönünün tersi pozitif kabul edilmiştir.

$$
M_{r}=\sum_{i=1}^{n} F_{s}(i)\left(\bar{y}(i)-\bar{y}_{a m}\right)+F_{c}\left(\bar{y}_{c}-\bar{y}_{a m}\right)
$$

Dikdörtgen kesitler için kesit ağırlık merkezinin ve basınç bileşke kuvvetinin yerleri, Denklem 2.9 yardımı ile elde edilir.

$$
\begin{aligned}
& \bar{y}_{a m}=\frac{h}{2} \\
& \bar{y}_{c}=h-\frac{k_{1} c}{2}
\end{aligned}
$$

\subsubsection{Tek Eksenli Bileşik Eğilme Durumunda Moment Kapasitesinin Hesaplanmast}

Eğilme etkisine ve ihmal edilemeyecek seviyede eksenel yüke maruz kalan elemanların tasarımı, moment - eksenel yük etkileşimi göz önüne alınarak, bileşik eğilme etkisinde yapılmaktadır. TS500-2000 ve T.B.D.Y.-2018' de bileşik eğilme tasarımı yapılması gereken eksenel yük oranı $\left(\mathrm{N} / \mathrm{N}_{0}\right)$ alt sınırı \%10 olarak tanımlanmıştır. Eksenel yük seviyesi, kesit moment kapasitesi üzerinde değişkenliğe sebep olmaktadır. Bileşik eğilmeye göre tasarımda ve moment $\left(\mathrm{M}_{\mathrm{r}}\right)$ - eksenel yük $\left(\mathrm{N}_{\mathrm{r}}\right)$ etkileşim hesaplarında, bu değişkenlik belirlenmektedir. Buna göre kesit moment kapasitesi, farklı eksenel yük değerleri için belirlenmekte ve kesitim moment kapasitesi tekil bir değer yerine bir zarf eğrisi şeklinde tespit edilmekte, dışmerkezliğe bağlı olarak $\mathrm{N}_{\mathrm{r}}-\mathrm{M}_{\mathrm{r}}$ etkileşim diyagramı üretilmektedir. Tek eksenli bileşik eğilme durumunda, kesit üzerinde sadece ortogonal olan tek bir eksen etrafındaki eğilme etkisi ve eksenel kuvvet etkileşimi göz önüne alınmaktadır.

a)

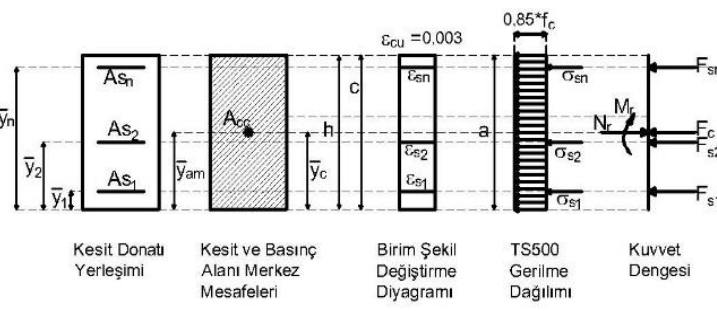

b) $\mathrm{c}=\mathrm{h}$

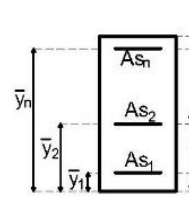

Kesit Donatı Yerleşimi Diyagramı

Dağılımı
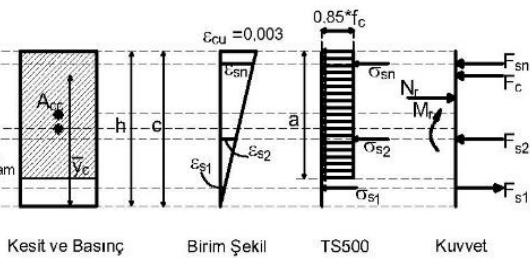
Alanı Merkez

\section{Birim Şekil}

Değiştirme
Diyagramı

$\begin{array}{ll}\text { TS500 } & \text { Kuvvet } \\ \text { Gerilme } & \text { Dengesi }\end{array}$

Gerilme
Dağılımı Dengesi

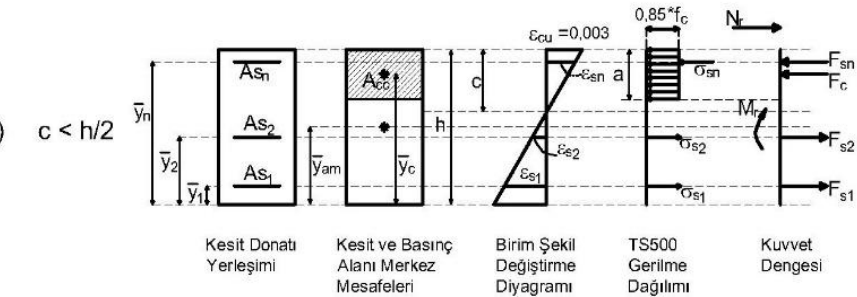

Şekil 2.5: Farklı tarafsız eksen değerlerine göre denge durumlarl a) $c=\infty, b) c=h, c) c<h / 2$
Basit eğilme durumunun incelendiği Bölüm 2.1.1'de verilen tüm denklemler, denge denklemi hariç aynı şekilde oluşturulur ve aynı adımlar gerçekleştirilir. Denklem (2.7)'de yer alan statik denge denklemi, $\mathrm{N}_{\mathrm{r}}$ eksenel basınç yükü de dikkate alınarak kurgulanır (Denklem 2.10).

$$
N_{r}=F_{c}+\sum_{i=1}^{n} F_{s}(i)
$$

Tarif edilen adımların uygulanması ile kesite etkidiği varsayılan herhangi bir eksenel yük değeri için statik dengeyi sağlayan tarafsız eksen derinliği ve buna bağlı moment kapasitesi elde edilebilmektedir. Etkileşim diyagramının daha pratik eldesi için söz konusu adımlar, eksenel yük varsayımı ve itrasyonu yerine, $c=0$ ve $c=\infty$ tarafsız eksen derinliği değerleri arasında varsayım ve iterasyon kullanılarak tekrarlanabilir. Varsayılan her bir c adımında, basit eğilme bölümündeki denklemler ile eksenel dış kuvvetin hesaba katıldığı Denklem 2.10'daki statik denge denklemi sağlanır. İlgili c için elde edilen sonuçlarla birlikte eksenel kuvvetin etkisi de hesaba katılarak, Denklem 2.8 yardımıla moment kapasitesi, $\mathrm{M}_{\mathrm{r}}$ belirlenir (Ersoy ve Özcebe 2012). Farklı c değerleri için elde edilen $N$ ve $M$ değerleri kullanılarak, moment - eksenel kuvvet karşılıklı etki diyagramı Şekil 2.6'da görüldüğü gibi oluşturulur.

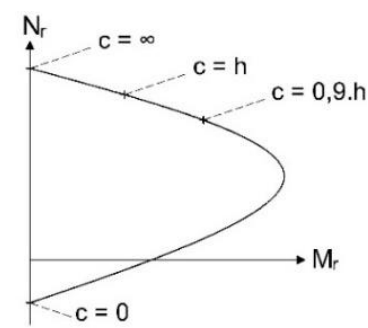

\section{Şekil 2.6: Moment-eksenel kuvvet karşıllılı etki diyagramı}

\subsection{2. İki Eksenli Bileşik Eğilme Durumunda Moment Kapasitesinin Hesaplanmast}

İki eksenli bileşik eğilme durumu, kest üzerindeki eğilme etkisinin ortogonal bir eksen etrafinda değil, rastgele bir açı ile oluşan eksen etrafında oluştuğu zorlama durumudur. Tek eksenli bileşik eğilme durumunda, eşdeğer basınç bloğunun alanı $\mathrm{A}_{\mathrm{cc}}$, kesitin formuna uygun olarak kolaylıkla hesaplanabilmektedir. Ancak iki eksenli bileşik eğilme durumunda $\mathrm{A}_{\mathrm{cc}}$, açı parametresi ile dikdörtgen kesitler için, üçgen, yamuk veya dörtgen formunda olabilir (Doğangün 2013). İki eksenli bileşik eğilmenin analitik çözümü, farklı alan hesapları ve koordinat dönüşümleri ile yapılabilmektedir.

Her farklı eksen açısı değeri için yeter sayıda c varsayımıyla ilgili açıda, ortogonal eksenlere ilişkin $\mathrm{M}_{\mathrm{rx}}$ ve $\mathrm{M}_{\mathrm{ry}}$ etkileşim diyagramı çıkartılabilmektedir.

Şekil 2.7'de görüleceği üzere beton basınç bloğu alanı, basit eğilme ve tek eksenli bileşik eğilme durumlarında olduğu gibi doğrudan eşdeğer basınç bloğu alanı olarak hesaplanabilmektedir.

Eğik düzlemdeki donatı uzamalarını hesaplayabilmek için ortogonal eksenlere göre tanımlanmış durumda olan donatı çubuklarının mesafeleri ve kesit yüksekliği h üzerinde, Denklem 2.11 ve Denklem 2.12 kullanılarak koordinat dönüşümü işlemleri yapilir. 
$h^{\prime}=b \sin \theta+h \cos \theta$

$\bar{y}^{\prime}(i)=\bar{x}(i) \sin \theta+\bar{y}(i) \cos \theta$

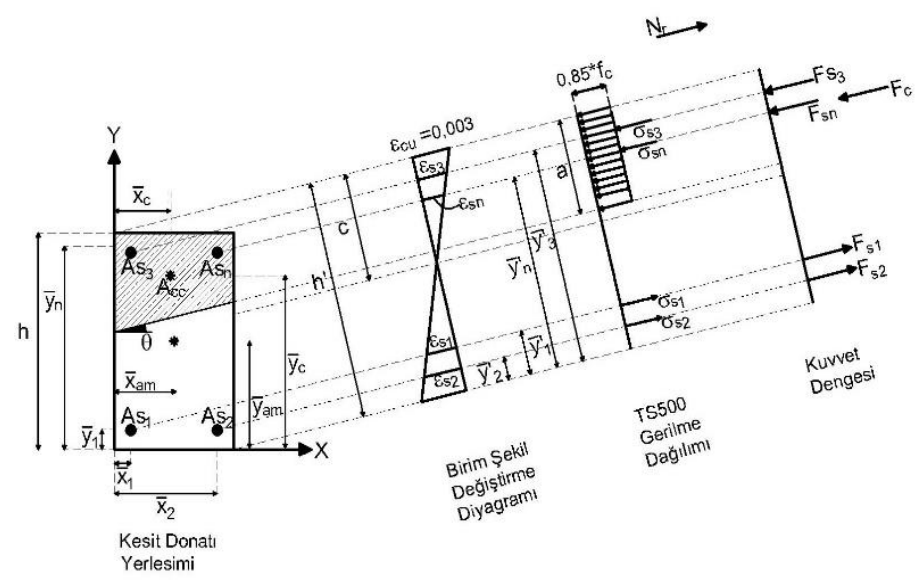

Şekil 2.7: Genel kuvvet dengesinin kurulmast

Yeni oluşturulan dönüştürülmüş mesafelerle, sırasıyla donatı uzamaları, donatı gerilmeleri, donatı kuvvetleri, beton bileşke kuvveti hesaplanır ve statik denge denklemi bağıntısı sağlanır (Denklem 2.13 - Denklem 2.17).

$$
\begin{aligned}
& \varepsilon_{s}(i) \\
& =\left(c-h^{\prime}+\bar{y}^{\prime}(i)\right)\left(\frac{\varepsilon_{c u}}{c}\right)
\end{aligned}
$$

\section{(Hata! Başvuru kaynağı}

bulunamadı..1) $\sigma_{s}(i)=\varepsilon_{s}(i) E_{s}$

$\left(\left|\varepsilon_{s}\right|\right.$ $\left.<f_{y} / E_{s}\right)$

$\sigma_{s}(i)=f_{y}$ $\left(\left|\varepsilon_{s}\right|\right.$ $\left.\geq f_{y} / E_{s}\right)$

(Hata! Başvuru kaynağı

(Hata! Başvuru kaynağı

$F_{s}(i)=\sigma_{s}(i) A_{s}(i)$

$F_{c}=0,85 f_{c} A_{c c}$

(Hata! Başvuru kaynağı

bulunamadı..4)

$N_{r}=F_{c}+\sum_{i=1}^{n} F_{s}(i)$

(Hata! Başvuru kaynağı

bulunamadı..5)
Yeterli sayıda açı değerleri için $\mathrm{M}_{\mathrm{rx}}, \mathrm{M}_{\mathrm{ry}}$ ve $\mathrm{N}_{\mathrm{r}}$ değerleri elde edilerek, üç boyutlu moment - eksenel yük etkileşim yüzeyi Şekil 2.8'deki gibi oluşturulur.

Yukarıda belirtilen işlem adımlarında $\mathrm{A}_{\mathrm{cc}}$ 'nin hesabı, basınç bloğunun formuna göre karmaşık hale gelebilmektedir. Ancak temel analitik geometri bilgisiyle veya daha ileri seviye sayısal çözümleme metotları ile bu alan hesaplanabilmektedir. Dikdörtgen kesitlerde eşdeğer basınç bloğu alanı için $\mathrm{k}_{1} \mathrm{c}$ ve $\Theta$ değerlerine bağlı olarak, $0^{\circ}$ ile $90^{\circ}$ arasında geçerli olan dört tip

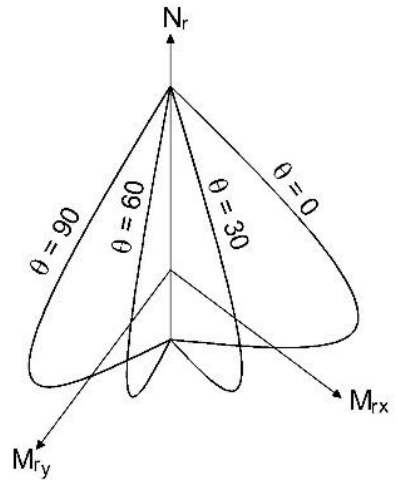

Şekil 2.8: Üç boyutlu etkileşim yüzeyi

alan formu hesaplanmıştır. Bu hesaplarda A, B ve C katsayıları temel analitik geometri ve benzerlik formülleri kullanılarak türetilmiştir (Denklem 21). Söz konusu dört farklı tip alana ait görseller Şekil 2.9'da, Şekil 2.10'da, Şekil 2.11'de ve Şekil 2.12 'de yer almaktadir.

$$
A=\frac{k_{1} c}{\cos \theta}
$$

(Hata! Başvuru kaynağı bulunamadı..9a)

$B=A-b \cdot \tan \theta$

kaynağı

bulunamadı..10b)

(Hata! Başvuru

kaynağı

$C=\frac{B}{\tan \theta}$
(Hata! Başvuru

Statik denge denklemi kurulduktan sonra ortogonal eksenlere göre aranan eğilme momenti, ilgili yöndeki kuvvet kolları kullanılarak elde edilir (Denklem 2.18 - Denklem 2.20).

$$
\begin{aligned}
M_{r x}=\sum_{i=1}^{n} F_{s}(i) & \left(\bar{y}(i)-\bar{y}_{a m}\right) \\
& +F_{c}\left|\bar{y}_{c}-\bar{y}_{a m}\right| \\
M_{r y}=\sum_{i=1}^{n} F_{s}(i)( & \left.\bar{x}(i)-\bar{x}_{a m}\right) \\
& +F_{c}\left|\bar{x}_{c}-\bar{x}_{a m}\right|
\end{aligned}
$$

(Hata!

Başvuru

kaynă̆

bulunamadı..6)

(Hata!

Başvuru

kaynağı

bulunamadı..7)

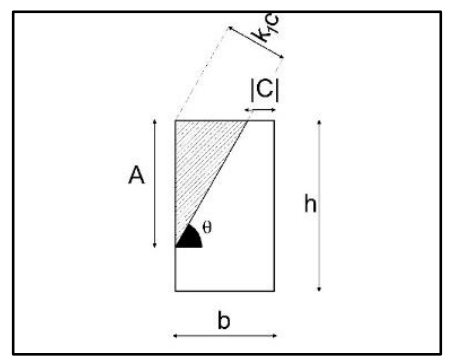

a)

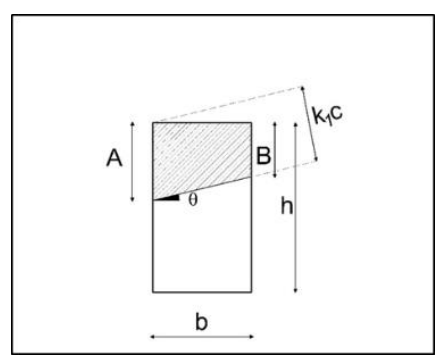

b)

(Hata!

Başvuru 


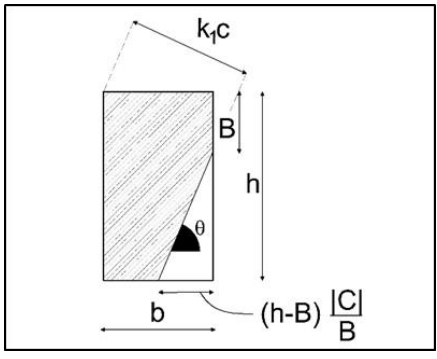

c)

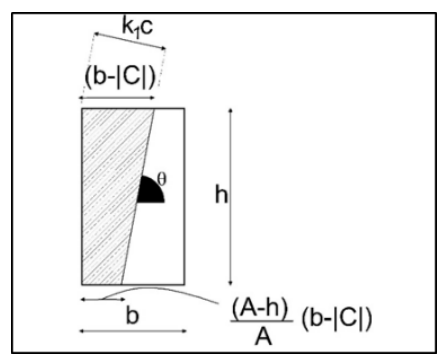

d)
Şekil 2.9: Ĕgik ĕgilme için tanımlanan dört farklı tipteki eşdeğer basınç bloğu alanları a) $A<h$ ve $B<0$ durumu, b) $A<h$ ve $B>0$ durumu, c) $A>h$ ve $B>0$ durumu, d) $A>h$ ve $B<0$ durumu

\section{Araştırma Sonuçları ve Tartışma}

Bu çalışma kapsamında, Bölüm-2'de anlatılan analitik yöntemlerle, üç boyutlu moment - eksenel kuvvet etkileşim zarfi oluşturulmuştur. Oluşturulan etkileşim zarf diyagramları, SAP2000 Section Designer modülünden ve XTRACT programından elde edilen zarf diyagramları ile karşılaştırılmıştır (SAP2000 2005, Xtract 2001).

XTRACT programı fiber modele göre çözüm yapmaktadır. Program, malzemeler için gerçek davranış modellerini kullanmak üzere tasarlanmıştır. Çalışmadaki kesit analizleri için programda donatı modeli, TS500-2000 varsayımında olduğu gibi elasto plastik olarak tanımlanmıştır. Diğer sonuçlar ile kıyaslama yapabilmek amacıyla, eşdeğer basınç bloğu varsayımında kullanıldığı üzere, beton dayanımı $0,85 \mathrm{f}_{\mathrm{c}}$ olacak biçimde beton modeli oluşturularak programa tanımlanmıştır (Xtract 2001).

SAP2000 programında fiber model yerine $\phi$ katsayıs olmaksızın ACI 318-14 yönetmeliğine göre çözüm tercih edilmiştir. Eşdeğer basınç bloğu varsayımı, uygulamalarda kullanılan C25 beton dayanımı için TS500 ile aynıdır (SAP2000 2005)

Bu durumda, Bölüm 2'de algoritması verilen ve çalışmada bir bilgisayar kodu yazılarak kullanınlan analitik yöntem ile SAP2000 Section Designer modülü sonuçlarının yakın olması beklenmektedir. Kurgulanan analitik hesap metoduna dayanan programda, diğer iki programdan farklı olarak donatı çubuk alanlarının beton basınç bloğu alanından çıkartılmamıştır.

\subsection{Simetrik Donatılı Kare Kesit için Üç Boyutlu Etkileşim Yüzeyinin Oluşturulması}

Bu bölümde, iki ana eksene göre simetrik donatılı, kare bir betonarme kesit için Bölüm 2'de açıklanmış hesap adımlarından oluşan ve analitik yöntemin baz alındığı bilgisayar programı sonuçları ile SAP2000 Section Designer modülü ve XTRACT programı sonuçları karşılaştırılmıştır.

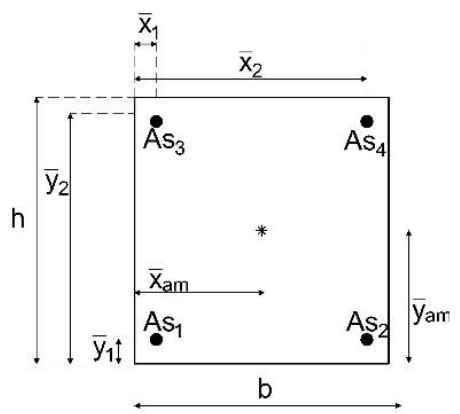

\begin{tabular}{|l|l|}
\hline$b(\mathrm{~mm})$ & 500 \\
\hline$h(\mathrm{~mm})$ & 500 \\
\hline $\bar{x}_{a m}(\mathrm{~mm})$ & 250 \\
\hline $\bar{y}_{a m}(\mathrm{~mm})$ & 250 \\
\hline
\end{tabular}

Şekil 3.1: Simetrik donatılı kare kesite ait görünüm ve boyut bilgileri

Tablo 3.1: Donatı Bilgileri

\begin{tabular}{|l|c|c|c|}
\hline No & $x(\mathrm{~mm})$ & $y(\mathrm{~mm})$ & çap $(\mathrm{mm})$ \\
\hline 1 & 35 & 35 & 20 \\
\hline 2 & 35 & 465 & 20 \\
\hline 3 & 465 & 465 & 20 \\
\hline 4 & 465 & 35 & 20 \\
\hline
\end{tabular}

Şekil 3.1'de, üzerinde hesaplamaların yapıldığı, simetrik donatılı kare kolonun kesit görüntüsü ve boyutlara ilişkin bilgiler yer almaktadır. Tablo 3.1'de ve Tablo 3.2'de, sirasıyla, donatı yerleşim bilgileri ve malzeme özellikleri görülmektedir.

İncelenen kesit simetrik olduğundan dolay $1,0^{\circ}, 30^{\circ}$ ve $45^{\circ}$ açıları için etkileşim diyagramları oluşturulmuş durumdadır. $\mathrm{Bu}$ değerlerin devamındaki eşlenik açılar için diyagramlar aynıdır $\left(0^{\circ}\right.$ ile $90^{\circ}$ ve $30^{\circ}$ ile $60^{\circ}$ ).

Tablo 3.2: Malzeme Bilgileri

\begin{tabular}{|c|l|c|}
\hline Beton & $\varepsilon_{c u}$ & 0,003 \\
\hline \multirow{3}{*}{ Çelik } & $f_{c}(\mathrm{Mpa})$ & 25 \\
\cline { 2 - 3 } & $k_{1}$ & 0,85 \\
\cline { 2 - 3 } & $f_{y}(\mathrm{Mpa})$ & 420 \\
\hline & $E_{S}(\mathrm{Mpa})$ & 200.000 \\
\hline
\end{tabular}

Şekil 3.2'de görüldüğü üzere, SAP2000 kesit analizi sonuçlarında, eksenel yük kapasitesi değerleri belirli bir seviyeden sonra sabit kalmaktadır. SAP2000 Section Designer modülü, hesap temeli olarak kullanmakta olduğu ACI-318-14'e göre eksenel tasarım dayanımını sınırlamaktadır ve grafilerde söz konusu yatay çizgi, bu nedenle ortaya çıkmaktadır (ACI 318-14 2014). Değerlendirmelerde bu sınır değere göz ardı edilmiştir. 
a)

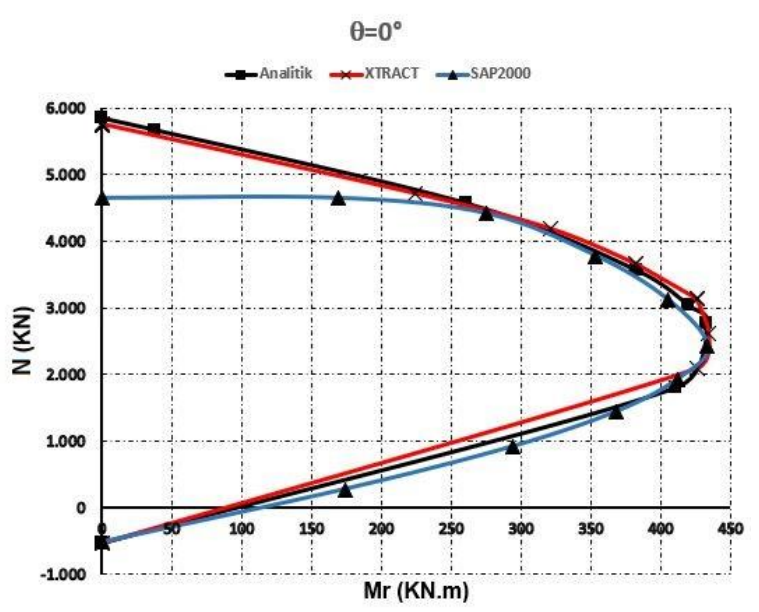

b)
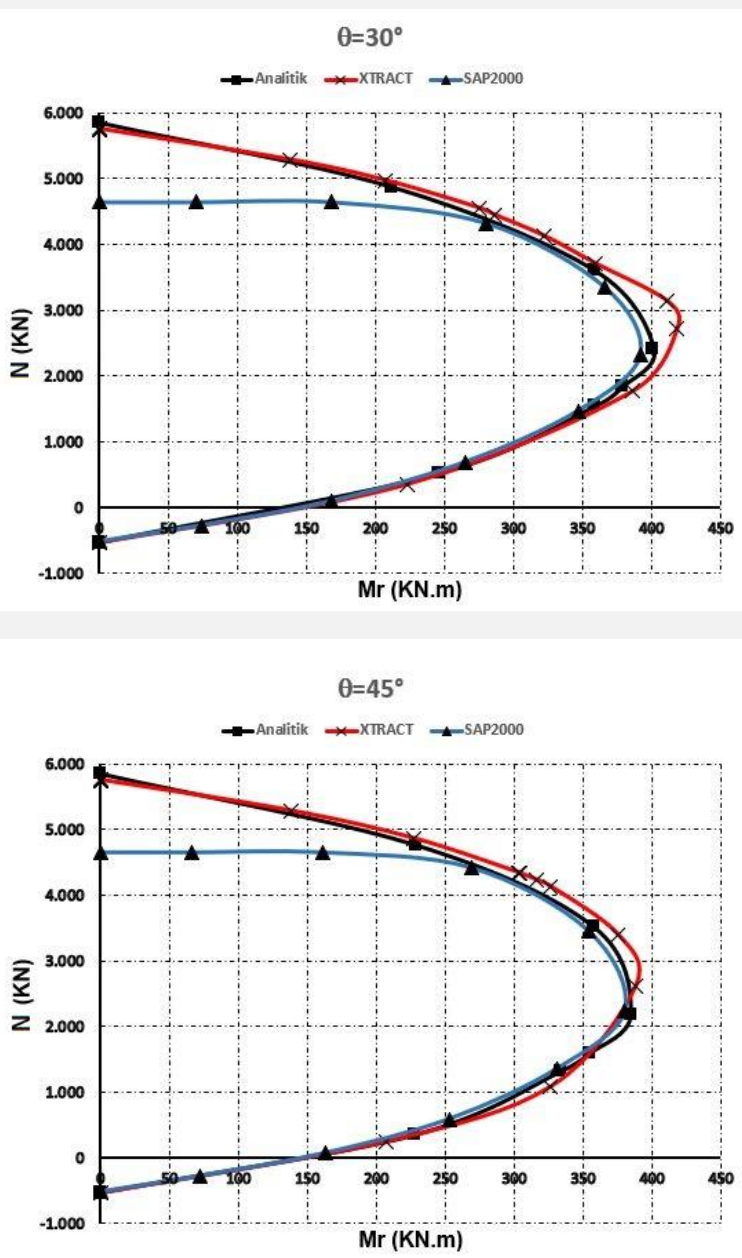

Şekil 3.2: Simetrik donatılı kare kesit için $\theta=0^{\circ}, 30^{\circ}$ ve $45^{\circ}$ açılarındaki moment - eksenel yük etkileşim diyagramları

Şekil 3.2 a'daki durumda, $\Theta=0^{\circ}$ olduğu için $\mathrm{M}_{\mathrm{ry}}$ etkisi bulunmamakta ve söz konusu durumda salt $\mathrm{N}-\mathrm{M}_{\mathrm{rx}}$ etkileşimi görülmektedir. Her üç yol ile elde edilen elde edilen sonuçların birbirine yakın olduğu, çekme etkin bölgede oldukça küçük bir farklılaşmanın bulunduğu belirlenmiş̧tir.

Şekil 3.2 b'deki $\Theta=30^{\circ}$ durumuna göre, kurgulanan analitik yöntem ve SAP2000 sonuçlarının birbirine çok yakın çıktığı, buna karşın bu sonuçların özellikle denge bölgesinde, XTRACT programından elde edilenden göreli olarak farklı olduğu anlaşılmıştır.
Şekil 3.2 c'ye göre $\Theta=45^{\circ}$ durumuna, SAP2000 sonuçları ile kurgulanan analitik yöntem sonuçlarının, yine birbirine çok yakın olduğu ve XTRACT programı sonuçlarının diğer sonuçlara yakın olduğu görülmüştür (aradaki fark, $\Theta=30^{\circ}$ için oluşandan çok daha azdır ve farklılık basınç etkin bölgeye kaymıştır).

Her üç kesit analizine ait etkileşim diyagramlarının, birbirinden farklı eksenel yük noktalarında türetilebildiği ve bu noktaların düzgünleştirilmiş çizgilerle birleştirildiği göz ardı edilmemelidir. Buradaki sayısal uygulama için $\Theta=30^{\circ}$ eğik eksen durumuna ait örnek hesap özetleri, Tablo 3.3 'de gösterilmiştir.

\subsection{Asimetrik Donatılı Dikdörtgen Kesit için Üç Boyutlu Etkileşim Yüzeyinin Oluşturulması}

$\mathrm{Bu}$ bölümde, iki ana eksene göre asimetrik donatıll, dikdörtgen bir betonarme kesit için Bölüm 2'de açıklanmış hesap adımlarından oluşan ve analitik yöntemin baz alındığı bilgisayar programı sonuçları ile SAP2000 Section Designer modülü ve XTRACT programı sonuçları karşılaştırılmıştır.

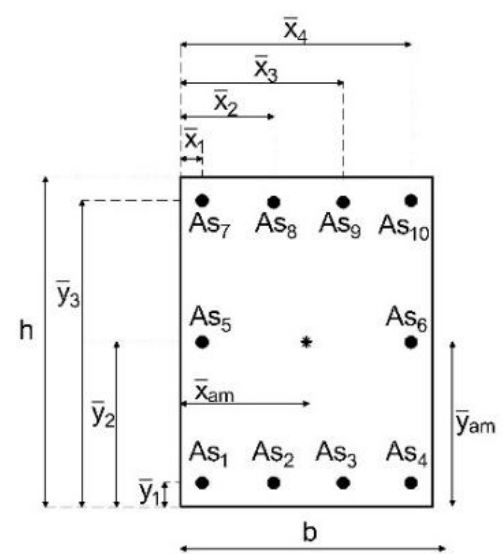

\begin{tabular}{|l|l|}
\hline$b(\mathrm{~mm})$ & 400 \\
\hline$h(\mathrm{~mm})$ & 600 \\
\hline $\bar{x}_{a m}(\mathrm{~mm})$ & 200 \\
\hline $\bar{y}_{a m}(\mathrm{~mm})$ & 300 \\
\hline
\end{tabular}

Şekil 3.3: Asimetrik donattlı dikdörtgen kesite ait görünüm ve boyut bilgileri

Tablo 3.4: Donatı Bilgileri

\begin{tabular}{|l|l|l|l|}
\hline No & $\mathrm{x}(\mathrm{mm})$ & $\mathrm{y}(\mathrm{mm})$ & çap $(\mathrm{mm})$ \\
\hline 1 & 35 & 35 & 16 \\
\hline 2 & 145 & 35 & 16 \\
\hline 3 & 255 & 35 & 16 \\
\hline 4 & 365 & 35 & 16 \\
\hline 5 & 35 & 265 & 16 \\
\hline 6 & 365 & 265 & 16 \\
\hline 7 & 35 & 565 & 16 \\
\hline 8 & 145 & 565 & 16 \\
\hline 9 & 255 & 565 & 16 \\
\hline 10 & 365 & 565 & 16 \\
\hline
\end{tabular}

Tablo 3.5: Malzeme Bilgileri

\begin{tabular}{|l|l|l|}
\hline \multirow{3}{*}{ Beton } & $\varepsilon_{c u}$ & 0,003 \\
\cline { 2 - 3 } & $f_{c}(\mathrm{Mpa})$ & 25 \\
\cline { 2 - 3 } & $k_{1}$ & 0,85 \\
\hline \multirow{3}{*}{ Çelik } & $f_{y}(\mathrm{Mpa})$ & 420 \\
\cline { 2 - 3 } & $E_{S}(\mathrm{Mpa})$ & 200.000 \\
\hline
\end{tabular}


İncelenen kesit asimetrik olduğundan dolayı $\Theta=0^{\circ}, 30^{\circ}, 45^{\circ}$, $60^{\circ}$ ve $90^{\circ}$ açıları için etkileşim diyagramları ayrı ayrı oluşturulmuş durumdadır.

Şekil 3.4'deki etkileşim diyagramlarında görüldüğü gibi Bölüm 3.1'de olduğu gibi burada da SAP2000 kesit analizi sonuçlarında, eksenel yük kapasitesi belirli bir değerde sabit kalmakta. Bu durum açıklanmış olduğu üzere ilgili programın baz aldığ şartname kaynaklıdır ve bu çalışmadaki değerlendirmelerde göz ard1 edilmiştir.

Şekil 3.4 a ve e'den görüldüğü üzere, simetrik donatılı kare kesitte olduğu gibi $0^{\circ}$ ve $90^{\circ}$ olan ana eksenlerdeki etkileşim diyagramları için üç analiz sonuçları da oldukça birbirine yakındır.

Şekil 3.4 b, c ve d'den görüldüğü üzere, $30^{\circ}, 45^{\circ}$ ve $60^{\circ}$ durumlar için etkileşim diyagramları, özellikle denge bölgesinde kullanılan yönteme göre farklılık göstermiştir. $\mathrm{Bu}$ farklılık, kurgulanan analitik prosedür ile SAP2000 kesit analizi arasında ihmal edilebilecek seviyede azdır. Ancak diyagramlar arasındaki fark, bu iki yöntem ile XTRACT kesit analizi arasında ciddi seviyededir. Söz konusu farkın, $45^{\circ}$ ve $60^{\circ}$ (zayıf eksene en yakın açılı durum) eğik eğilme durumlarında çok daha belirgin olduğu görülmüştür.

\section{Sonuç}

Kolonlar, yapıyı ayakta tutan ve deprem yüklerine karşı koyan düşey taşıyıcı elemanlardır. Kolonlarda eğilme tasarımı, eksenel yükün eğilme momentiyle birlikte değerlendirildiği, moment eksenel yük etkileşimine göre yapılmaktadır. Kesit ana aksları etrafinda söz konusu etkileşim diyagramlarının üretilmesi oldukça basitken, gerçek durumdaki kesit üzerinde eğik eksende moment ektisinde, bu etkileşimin hesabı komplike hale gelmektedir.

Tablo 3.3: $\theta=30^{\circ}$ eğik eksen durumuna ait etkileşim diyagramı örnek hesap tablosu

\begin{tabular}{|c|c|c|c|c|c|c|c|c|c|}
\hline$c$ & $(\mathrm{~mm})$ & $\infty$ & 600 & 475 & 375 & 325 & 300 & 200 & 0 \\
\hline$a$ & $(\mathrm{~mm})$ & $\infty$ & 510,0 & 403,8 & 318,8 & 276,3 & 255,0 & 170,0 & 0,0 \\
\hline$A_{c c}$ & $\left(\mathrm{~mm}^{2}\right)$ & 250.000 & 215.436 & 160.936 & $\begin{array}{r}111.86 \\
2\end{array}$ & 87.324 & 75.056 & 33.371 & 0 \\
\hline $\bar{y}_{c}$ & $(\mathrm{~mm})$ & 250 & 279 & 328 & 373 & 393 & 402 & 435 & 500 \\
\hline $\bar{x}_{c}$ & $(\mathrm{~mm})$ & 250 & 228 & 213 & 196 & 181 & 170 & 113 & 0 \\
\hline $\bar{y}^{\prime}(1)$ & $(\mathrm{mm})$ & 47,8 & 47,8 & 47,8 & 47,8 & 47,8 & 47,8 & 47,8 & 47,8 \\
\hline $\bar{y}^{\prime}(2)$ & $(\mathrm{mm})$ & 420,2 & 420,2 & 420,2 & 420,2 & 420,2 & 420,2 & 420,2 & 420,2 \\
\hline $\bar{y}^{\prime}(3)$ & $(\mathrm{mm})$ & 635,2 & 635,2 & 635,2 & 635,2 & 635,2 & 635,2 & 635,2 & 635,2 \\
\hline $\bar{y}^{\prime}(4)$ & $(\mathrm{mm})$ & 262,8 & 262,8 & 262,8 & 262,8 & 262,8 & 262,8 & 262,8 & 262,8 \\
\hline $\mathrm{f}_{l}(1)$ & $(\mathrm{mm})$ & 20 & 20 & 20 & 20 & 20 & 20 & 20 & 20 \\
\hline $\mathrm{f}_{l}(2)$ & $(\mathrm{mm})$ & 20 & 20 & 20 & 20 & 20 & 20 & 20 & 20 \\
\hline $\mathrm{f}_{l}(3)$ & $(\mathrm{mm})$ & 20 & 20 & 20 & 20 & 20 & 20 & 20 & 20 \\
\hline $\mathrm{f}_{l}(4)$ & $(\mathrm{mm})$ & 20 & 20 & 20 & 20 & 20 & 20 & 20 & 20 \\
\hline$\varepsilon_{S}(1)$ & & 0,0030 & $-0,0002$ & $-0,0010$ & $-0,0021$ & $-0,0029$ & $-0,0034$ & $-0,0065$ & $-0,1$ \\
\hline$\varepsilon_{S}(2)$ & & 0,0030 & 0,0017 & 0,0013 & 0,0009 & 0,0006 & 0,0004 & $-0,0009$ & $-0,1$ \\
\hline$\varepsilon_{S}(3)$ & & 0,0030 & 0,0028 & 0,0027 & 0,0026 & 0,0026 & 0,0025 & 0,0023 & $-0,1$ \\
\hline$\varepsilon_{S}(4)$ & & 0,0030 & 0,0009 & 0,0003 & $-0,0004$ & $-0,0009$ & $-0,0012$ & $-0,0033$ & $-0,1$ \\
\hline$\sigma_{S}(1)$ & $(M P a)$ & 420,0 & $-35,2$ & $-202,4$ & $-416,3$ & $-420,0$ & $-420,0$ & $-420,0$ & $-420,0$ \\
\hline$\sigma_{s}(2)$ & $(M P a)$ & 420,0 & 337,2 & 268,0 & 179,5 & 114,8 & 74,4 & $-188,4$ & $-420,0$ \\
\hline$\sigma_{s}(3)$ & $(M P a)$ & 420,0 & 420,0 & 420,0 & 420,0 & 420,0 & 420,0 & 420,0 & $-420,0$ \\
\hline$\sigma_{S}(4)$ & $(M P a)$ & 420,0 & 179,8 & 69,2 & $-72,3$ & $-175,8$ & $-240,4$ & $-420,0$ & $-420,0$ \\
\hline$F_{S}(1)$ & $(k N)$ & 131,9 & $-11,1$ & $-63,5$ & $-130,7$ & $-131,9$ & $-131,9$ & $-131,9$ & $-131,9$ \\
\hline$F_{S}(2)$ & $(k N)$ & 131,9 & 105,9 & 84,2 & 56,4 & 36,1 & 23,4 & $-59,2$ & $-131,9$ \\
\hline$F_{S}(3)$ & $(\mathrm{kN})$ & 131,9 & 131,9 & 131,9 & 131,9 & 131,9 & 131,9 & 131,9 & $-131,9$ \\
\hline$F_{S}(4)$ & $(k N)$ & 131,9 & 56,5 & 21,7 & $-22,7$ & $-55,2$ & $-75,5$ & $-131,9$ & $-131,9$ \\
\hline$F_{C}$ & $(\mathrm{kN})$ & $5.312,5$ & $4.578,0$ & $3.419,9$ & $2.377,1$ & $1.855,6$ & $1.594,9$ & 709,1 & 0,0 \\
\hline$N_{r}$ & $(k N)$ & $5.840,0$ & $4.861,2$ & $3.594,1$ & $2.411,9$ & $1.836,5$ & $1.542,8$ & 518,1 & $-527,5$ \\
\hline$M_{r x}(1)$ & $(k N . m)$ & $-28,4$ & 2,4 & 13,7 & 28,1 & 28,4 & 28,4 & 28,4 & 28,4 \\
\hline$M_{r x}(2)$ & $(k N . m)$ & 28,4 & 22,8 & 18,1 & 12,1 & 7,8 & 5,0 & $-12,7$ & $-28,4$ \\
\hline$M_{r x}(3)$ & $(k N . m)$ & 28,4 & 28,4 & 28,4 & 28,4 & 28,4 & 28,4 & 28,4 & $-28,4$ \\
\hline$M_{r x}(4)$ & $(k N . m)$ & $-28,4$ & $-12,1$ & $-4,7$ & 4,9 & 11,9 & 16,2 & 28,4 & 28,4 \\
\hline$M_{r x}(\mathrm{c})$ & $(k N . m)$ & 0,0 & 134,7 & 267,7 & 291,5 & 265,0 & 242,1 & 130,9 & 0,0 \\
\hline$M_{r x}$ & $(k N . m)$ & 0,0 & 176,1 & 323,1 & 364,9 & 341,3 & 320,1 & 203,2 & 0,0 \\
\hline$M_{r y}(1)$ & $(k N . m)$ & $-28,4$ & 2,4 & 13,7 & 28,1 & 28,4 & 28,4 & 28,4 & 28,4 \\
\hline$M_{r y}(2)$ & $(k N . m)$ & $-28,4$ & $-22,8$ & $-18,1$ & $-12,1$ & $-7,8$ & $-5,0$ & 12,7 & 28,4 \\
\hline$M_{r y}(3)$ & $(k N . m)$ & 28,4 & 28,4 & 28,4 & 28,4 & 28,4 & 28,4 & 28,4 & $-28,4$ \\
\hline$M_{r y}(4)$ & $(k N . m)$ & 28,4 & 12,1 & 4,7 & $-4,9$ & $-11,9$ & $-16,2$ & $-28,4$ & $-28,4$ \\
\hline$M_{r y}(\mathrm{c})$ & $(k N . m)$ & 0,0 & 98,9 & 127,8 & 127,8 & 127,8 & 127,8 & 96,9 & 0,0 \\
\hline$M_{r y}$ & $(k N . m)$ & 0,0 & 119,0 & 156,4 & 167,3 & 164,9 & 163,3 & 138,0 & 0,0 \\
\hline
\end{tabular}


Avrupa Bilim ve Teknoloji Dergisi

\begin{tabular}{|l|l|l|l|l|l|l|l|r|r|}
\hline$M_{r}$ & (kN.m) & 0,0 & 212,5 & 359,0 & 401,4 & 379,0 & 359,3 & 245,6 & 0,0 \\
\hline
\end{tabular}


a)
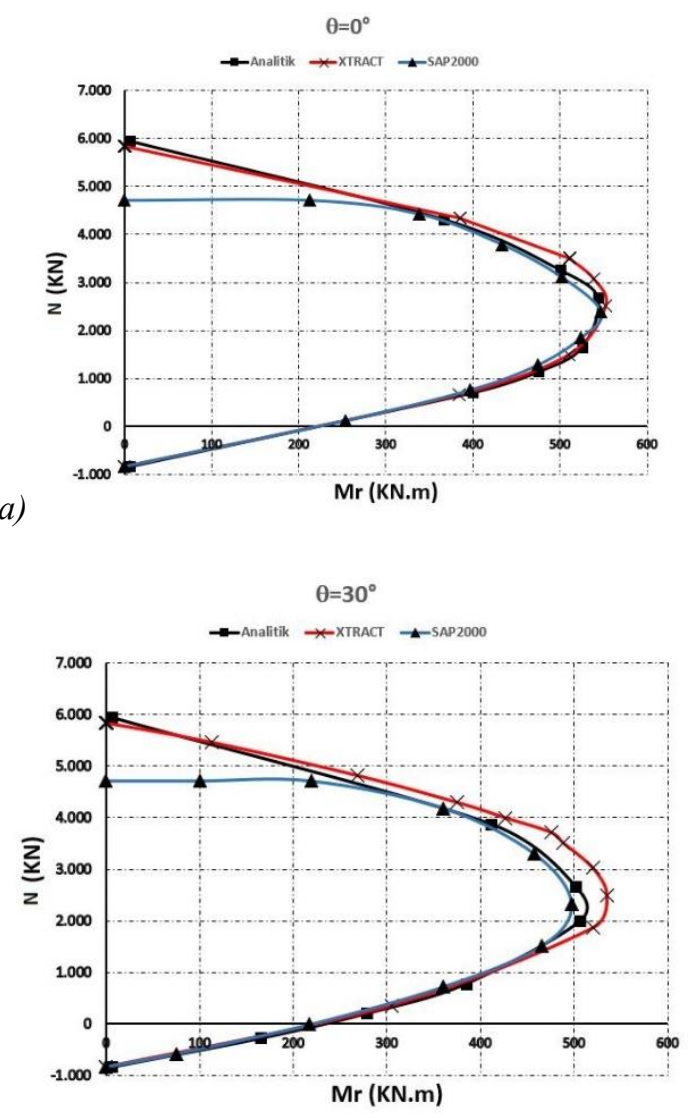

$b$

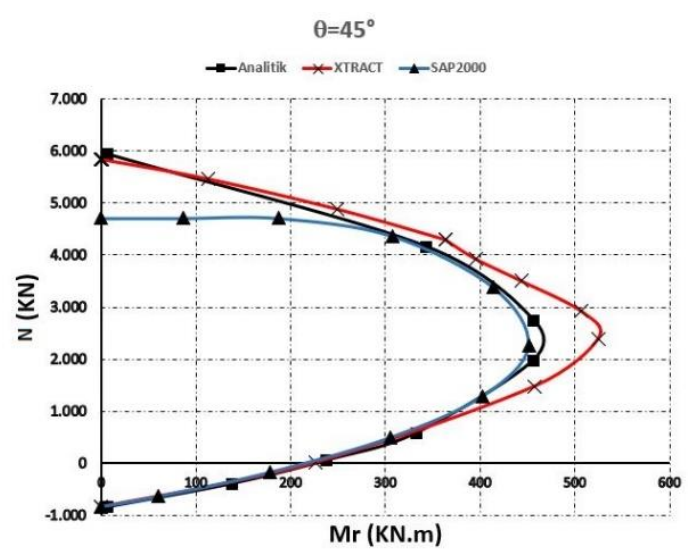

$c$

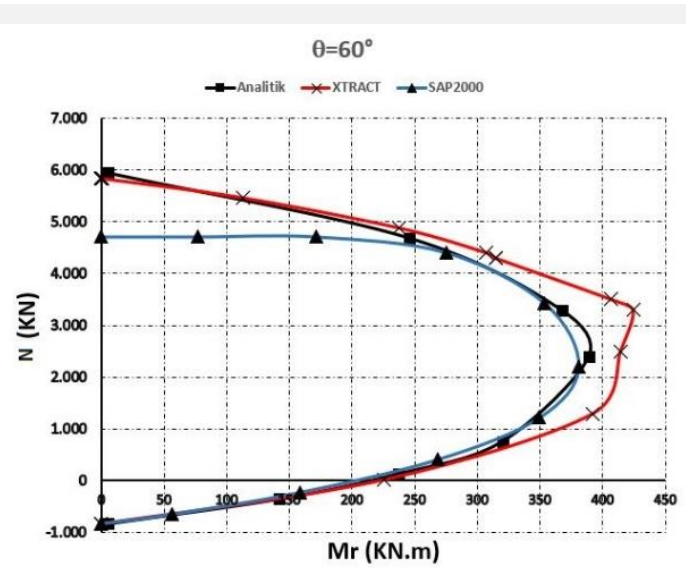

Şekil 3.4 dvm.: Asimetrik donatılı dikdörtgen kesit için $\theta=0^{\circ}, 30^{\circ}, 45^{\circ}, 60^{\circ}$ ve $90^{\circ}$ açılarındaki moment-eksenel yük etkileşim diyagramları

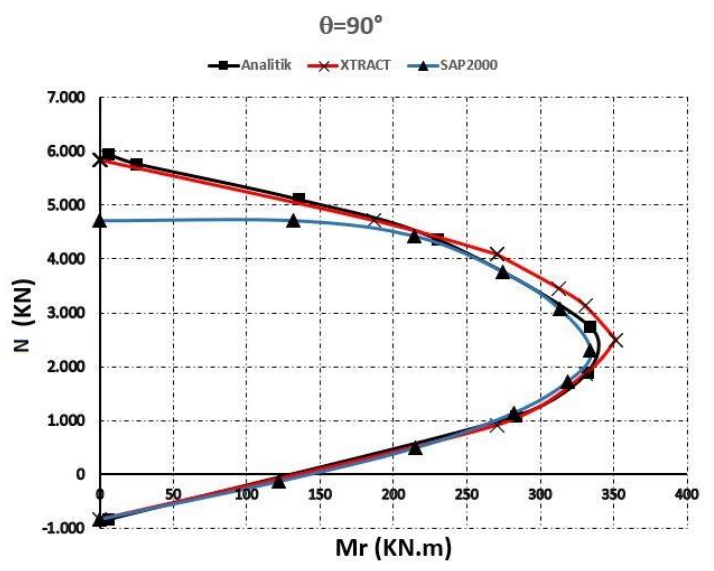

e)

Şekil 3.4 dvm.: Asimetrik donatılı dikdörtgen kesit için $\theta=0^{\circ}, 30^{\circ}, 45^{\circ}, 60^{\circ}$ ve $90^{\circ}$ açllarındaki moment - eksenel yük etkileşim diyagramları

Bu çalışma kapsamında kare ve dikdörtgen betonarme kesitler için iki eksenli moment - eksenel yük etkileşim diyagramları, kurgulanan analitik yöntemle ve bilgisayar kodlaması yardımıyla hesaplanmış ve uluslararası geçerliliği olan ve iki farklı ticari bilgisayar programlarının sonuçları ile karşılaştırılmıştır. Söz konusu ticari yazılımlardan biri, kesit analizi için manuel çözümdeki analitik yaklaşımın aynısı kullanırken (opsiyonel), diğeri kesit analizi için fiber metodu kullanmaktadır. Böylelikle iki eksenli eğik eğilme durumunda, moment - eksenel yük etkileşim diyagramlarında, analitik metod manuel ve ticari yazılım olarak kıyaslanmış, ayrıca bu sonuçlarla da fiber metodun kıyaslaması yapılabilmştir.

Tek eksenli bileşik eğilme durumunda $\left(0^{\circ}\right.$ ve $\left.90^{\circ}\right)$, her iki prizmatik kesit tipi için de manuel analitik, ticari program tabanlı analitik ve fiber metodlar, moment - eksenel yük diyagramlarını çok yakın biçimde üretmektedirler.

Çalışma kapsamında gerçekleştirilen sayısal uygulamalardan anlaşıldığı üzere, tek eksenli bileşik eğilme durumu dışında kalan eğik eksenli bileşik eğilme durumlarında, manuel analitik yöntem ile SAP2000 sonuçlarının (analitik metod opsiyonuyla) benzer olduğu, fiber metod kullanan XTRACT sonuçlarının göreli olarak farklı olduğu görülmüştür. Bu farklılığın özellikle denge konumu civarında kendini gösterdiği ve fiber metod ile daha yüksek kapasitelerin hesaplandığ ve SAP2000 aynı varsayımlarla eşdeğer basınç bloğu yaklaşımı yaparken, XTRACT programı doğrusal olmayan beton modelleri kullanmaktadır. Doğrusal olmayan davranışı yakınsayan eşdeğer basınç bloğu yaklaşımının, kesit ortogonal ana eksenlerindeki moment - eksenel yük etkileşimlerinin hesabı için oldukça doğru bir kabulken, ara açılardaki eğik bileşik eğilme durumlarında gerçekten uzaklaştığı anlaşılmıştır.

Günümüzde kullanılan paket programların birçoğu, iki eksenli bileşik eğilme hesapları için analitik yöntemlerle çözüm yapmaktadır. Analitik yöntem, fiber yönteme göre güvenli tarafta kalma koşulunu sağlamaktadır. Ancak özellikle köşe ve dikdörtgen kolonlarda, doğrusal olmayan deprem hesaplarında kullanılan plastik mafsalların ve buna bağlı kesit hasar seviyesinin tayini, bu yöntemle ekonomik sonuçlar vermeyebilir. Bu gibi durumlarda fiber yöntemin daha uygun olduğu değerlendirmesine ulaşılmıştır. 


\section{Kaynakça}

ACI 318-14. (2014). Building code requirements for structural concrete. American Concrete Institute, Farmington Hills.

Doğangün, A.(2013). Betonarme yapıların hesap ve tasarımı. İstanbul: Birsen.

Ersoy, U. ve Özcebe G. (2012). Betonarme. İstanbul: Evrim.

Moehle, J. (2015). Seismic Design of Reinforced Concrete Buildings. McGraw-Hill Education

SAP2000, Computers and Structures. (2005). Structure Analysis Program. California.

TS500. (2000). Betonarme yapıların tasarımı ve yapım kuralları. Türk Standartları Enstitüsü, Ankara.

Topçu, A. (2013). Betonarme 1 ders notları. http://mmf2.ogu.edu.tr/atopcu

Wang, G. G. and Hsu, C. T. (1992). Complete Biaxial LoadDeformation Behavior of RC Columns. Journal of Structural Engineering, Vol.18, No. 9, September.

Xtract, Imbsen Software System. (2001). Cross Sectional Analysis of Components. California.

T.B.D.Y Türkiye Bina Deprem Yönetmeliği. 18 Mart 2018 Tarih ve 30364 Sayılı Resmi Gazete. 2018 